\title{
КЛІНІКО-ЛАБОРАТОРНІ ОСОБЛИВОСТІ ХАРАКТЕРИСТИКИ РЕТРОСПЕКТИВНОГО АНАЛІЗУ ОБСТЕЖЕННЯ ЖІНОК ІЗ ВНУТРІШНЬОЕПІТЕЛІАЛЬНОЮ НЕОПЛАЗІЕЮ ШИЙКИ МАТКИ
}

Мета дослідження - ретроспективна оцінка особливостей анамнезу внутрішньоепітеліальної неоплазії шийки матки.

Матеріали і методи. У дослідженні проведено ретроспективний аналіз історій хвороб 450 пацієнток із патологією шийки матки (ПШМ) у порівнянні з 30 гінекологічно здоровими пацієнтками. Для уточнення ролі деяких анамнестичних чинників у розвитку ПШМ в обстежених пацієнток ми проаналізували наявність спадкової схильності, характер та особливості менструальної і репродуктивної функцій.

Результати дослідження та їх обговорення. Серед обстежених жінок першої групи було виявлено уреаплазмоз у 83,33 \% пацієнтів, мікоплазмоз - у 30,00 \% випадків, хламідіоз - у 43,33 \% жінок. Мікст інфрікування було виявлено в 76,67 \% пацієнтів. Поєднання даних інфекцій було виявлено в 83,33 \% хворих. Серед обстежених пацієнтів вірус простого герпесу (ВПГ) 1-го і 2-го типів мав місце у 16 (53,33 \%) пацієнтів, цитомегаловірус (ЦМВ) - у 12 (40,0 \%), вірус Епштейна-Барр (ЕБВ) - у 3 (10,0 \%) хворих. Поєднання кількох типів вірусів було відмічено у 36,67 \% жінок. При цитологічному дослідженні за допомогою рідинної цитології обстежених пацієнтів було виявлено LSIL у 76,67 \% пацієнтів, тоді як ASCUS - у 23,33 \%, a при ко-тестінгу, або рефрлекс тестуванні, у всіх пацієнтів виявлено HPV високоонкогенного типу. Аналітична оцінка вагомості фракторів ризику виникнення ПШМ дозволила припустити, що раннє менархе майже втричі збільшує шанси розвитку ПшМ (OR=2,72; 95 \% Cl: (1,02-5,11); p<0,002), порушення менструального циклу - вдвічі $(\mathrm{OR}=2,04 ; 95$ \% Cl: $(1,09-3,14) ; p<0,05)$, хронічні запальні захворювання придатків (OR=3,14; 95 \% Cl: $(0,91-5,14)$; $p<0,05)$.

Висновки. У пацієнток із патологією шийки матки доцільно проводити комплексну оцінку вагінальної мікст-інфекції та відповідну санацію і відновлення нормальної мікрофрлори для профрілактики розвитку патології шийки матки. Пацієнток із патологією шийки матки необхідно обстежувати на наявність вірусної інфекції і при тривалій персистенції ВПЛ та вірусів родини герпесу понад один рік необхідно застосовувати методику противірусної санації у широкій клінічній практиці.

Ключові слова: патологія шийки матки; папіломавірусна інсрекція; герпесвірусна інфекція; фрактори ризику.

КЛИНИКО-ЛАБОРАТОРНЫЕ ОСОБЕННОСТИ ХАРАКТЕРИСТИКИ РЕТРОСПЕКТИВНОГО АНАЛИЗА ОБСЛЕДОВАНИЯ ЖЕНЩИН С ВНУТРИЭПИТЕЛИАЛЬНОЙ НЕОПЛАЗИЕЙ ШЕЙКИ МАТКИ

Цель исследования - ретроспективная оценка особенностей анамнеза внутриэпителиальной неоплазии шейки матки.

Материалы и методы. В исследовании проведен ретроспективный анализ историй болезней 450 пациенток с патологией шейки матки (ПШМ) по сравнению с 30 гинекологически здоровыми пациентками. Для уточнения роли некоторых анамнестических фракторов в развитии ПШМ у обследованных пациенток мы проанализировали наличие наследственной предрасположенности, характер и особенности менструальной и репродуктивной функций.

Результаты исследования и их обсуждение. Среди обследованных женщин первой группы был обнаружен уреаплазмоз у 83,33 \% пациентов, микоплазмоз - в 30,00 \% случаев, хламидиоз-у 43,33\% женщин. Микст инсицирования был выявлен у 76,67 \% пациентов. Сочетание данных инорекций было обнаружено у 83,33 \% больных. Среди обследованных пациентов вирус простого герпеса (ВПГ) 1-го и 2-го типов имел место у 16 (53,33 \%) пациентов, цитомегаловирус (ЦМВ) - у 12 (40,0 \%), вирус ЭпштейнаБарр (ЭБВ) - у 3 (10,0 \%) больных. Сочетание нескольких типов вирусов было отмечено у 36,67 \% женщин. При цитологическом исследовании с помощью жидкостной цитологии обследованных пациентов было выявлен LSIL у 76,67 \% пациентов, тогда как ASCUS - у 23,33 \%, а при ко-тестинге, или рефлекс тестировании, у всех пациентов выявлено HPV высокоонкогенного типа. Аналитическая оценка значимости фракторов риска возникновения ПШМ позволила предположить, что раннее менархе почти втрое увеличивает шансы развития ПШМ (OR=2,72; 95 \% Cl: $(1,02-5,11)$, p<0,002), нарушения менструального цикла - вдвое (OR=2,04; 95 \% Cl: (1,09-3,14), p<0,05), хронические воспалительные заболевания яичников (OR=3,14; 95 \% Cl: $(0,91-5,14)$ p<0,05).

Выводы. У пациенток с патологией шейки матки целесообразно проводить комплексную оценку вагинальной микстинфекции и соответствующую санацию и восстановление нормальной микрофрлоры для профилактики развития патологии шейки матки. Пациенток с патологией шейки матки необходимо обследовать на наличие вирусной инфекции и при длительной персистенции ВПЧ и вирусов семейства герпеса более одного года необходимо применять методику противовирусной санации в широкой клинической практике.

Ключевые слова: патология шейки матки; папилломавирусная инфекция; герпесвирусная инфекция; фракторы риска.

CLINICAL AND LABORATORY FEATURES OF RETROSPECTIVE ANALYSIS CHARACTERISTICS EXAMINATION IN WOMEN WITH INTRAEPITHELIAL NEOPLASIA OF THE CERVIX

The aim of the study - retrospective assessment of the history features of intraepithelial neoplasia of the cervix.

Materials and Methods. The study carried out a retrospective analysis of the case histories of 450 patients with cervical pathology (CP) compared with 30 gynecologically healthy patients.

Results and Discussion. Among the examined women, ureoplasmosis was first detected in (83.33) patients, mycoplasmosis - $(30.00 \%)$ cases, chlamydia - $(43.33 \%)$ women. Mixed infection was detected in $76.67 \%$ of patients. The combination of these 
infections was found in (83.33\%) patients. Among the examined patients, herpes simplex virus (HSV) type $1 / 2-$ in 16 (53.33 \%), cytomegalovirus (CMV) - in 12 (40.0\%), EBV virus (Epstein-Barr) - in $3(10.0 \%)$ ) patients. The combination of several types of viruses was noted in $(36.67 \%)$ women. The combination of several types of viruses was noted in $(76.67 \%)$ women. When cytological examination using liquid cytology of the examined patients, LSIL was detected in (76.67\%) patients, while ASCUS - (23.33 \%), and when co-testing or reflex testing, HPV of a highly oncogenic type was revealed in all patients. An analytical assessment of the significance of risk factors for the onset of $\mathrm{CP}$ allowed us to assume that early menarche almost triples the chances of developing $\mathrm{CP}(\mathrm{OR}=2.72 ; 95 \% \mathrm{Cl}:(1.02-5.11), \mathrm{p}<0.002)$, disorders of the menstrual cycle - twice $(\mathrm{OR}=2.04 ; 95 \% \mathrm{Cl}:(1.09-3.14), \mathrm{p}$ $<0.05)$, chronic inflammatory diseases of applications (OR $=3.14 ; 95 \% \mathrm{Cl}:(0.91-5.14) \mathrm{p}<0.05)$.

Conclusions. In patients with cervical pathology, it is advisable to conduct a comprehensive assessment of vaginal mixed infection and appropriate rehabilitation and restoration of normal microflora to prevent the development of cervical pathology. Patients with cervical pathology should be examined for the presence of viral infection and with long-term persistence of HPV and herpes viruses for more than one year should use the technique of antiviral resuscitation in general clinical practice.

Key words: pathology of the cervix; papillomavirus infection; herpesvirus infection; risk factors.

вступ. Патологія шийки матки посідає одне 3 перших місць у структурі амбулаторної гінекологічної захворюваності та становить 15-40 \%, а у жінок, які не народжували, - до 52-90 \% [1-7]. Патологія шийки матки $€$ однією $з$ найважливіших у сучасній медицині, оскільки вимагає особливої уваги не тільки гінекологів, а й онкологів, імунологів та інших спеціалістів [1-3]. Тривалість захворювання, часті рецидиви, неадекватне лікування та приєднання вірусної інфекції можуть призвести до передракових процесів та раку шийки матки. В Україні ця патологія перебуває на другому місці та на сьомому серед усіх злоякісних пухлин [8, 9].

Оскільки хронічні персистуючі інфекції сечостатевого тракту в гінекологічних хворих, а особливо мікт-іноекції з вірусними компонентами супроводжуються ознаками вторинної імунної недостатності змішаного типу з переважним порушенням клітинної та гормональної ланок імунітету, пошук препаратів з імуноактивною дією в комплексному лікуванні патології шийки матки має патогенетичне підґрунтя [11-20].

METА ДОСЛІДЖЕННЯ - ретроспективна оцінка особливостей анамнезу внутрішньоепітеліальної неоплазії шийки матки.

МАТЕРІАЛИ І МЕТОДИ. У дослідженні проведено ретроспективний аналіз історій хвороб 450 пацієнток із патологією шийки матки (ПШМ) в порівнянні 330 гінекологічно здоровими пацієнтками. Для уточнення ролі деяких анамнестичних чинників у розвитку ПШМ в обстежених пацієнток ми проаналізували наявність спадкової схильності, характер та особливості менструальної і репродуктивної фрункцій.

У дослідження було включено 60 жінок віком від 18 до 42 років. Середній вік пацієнтів склав $(25,92 \pm 0,61)$ року. Критеріями включення пацієнтів у дослідження були: гістологічно підтверджена внутрішньоепітеліальна неоплазія шийки матки (CIN I), асоційована з вірусом папіломи людини високоонкогенного типу, та регулярний менструальний цикл, наявність статевих стосунків, інфікування вірусом папіломи людини понад один рік, відсутність консервативного та хірургічного лікування шийки матки, іншої гінекологічної, соматичної та ендокринної патології. Участь у дослідженні пацієнтки здійснювали на підставі письмової згоди.

Оцінка відмінностей між групами та їх помилки була проведена за допомогою t-критерію Манна-Уїтні та Стьюдента. Статистичну значимість визначили як $\mathrm{p}<0,05$.
РЕЗУЛЬТАТИ ДОСЛІДЖЕННЯ ТА ЇХ ОБГОВОРЕНня. Обстеження всіх пацієнтів розпочалося з вивчення скарг та збору анамнезу. Особливу увагу приділяли цервікальній інфекції, хворобам, що передаються статевим шляхом.

Серед обстежених жінок першої групи було виявлено уреаплазмоз у 83,33 \% пацієнтів, мікоплазмоз - у 30,00 \% випадків, хламідіоз - у 43,33 \% жінок. Мікст інфікування було виявлено в 76,67 \% пацієнтів. Поєднання даних інфекцій було виявлено в 83,33 \% хворих.

Серед обстежених пацієнтів вірус простого герпесу (ВПг) 1-го і 2-го типів мав місце у 16 (53,33 \%) пацієнтів, цитомегаловірус (ЦМВ) - у 12 (40,0\%), вірус ЕпштейнаБарр (ЕБВ) - у 3 (10,0 \%) хворих. Поєднання кількох типів вірусів було відмічено у $36,67 \%$ жінок.

При цитологічному дослідженні за допомогою рідинної цитології обстежених пацієнтів було виявлено LSIL у 76,67 \% пацієнтів, тоді як ASCUS - у 23,33 \%, а при ко-тестінгу, або рефлекс тестуванні, у всіх пацієнтів виявлено HPV високоонкогенного типу. Усі пацієнти були обстежені кольпоскопічно.

При вивченні родинного анамнезу обстеженихпацієнток було встановлено, що близькі родичі у $198(44,00 \pm 2,34) \%$ (OR=9,81; 95 \% Cl: $(0,68-10,53) ; p<0,002)$ випадках страждали від запальних захворювань матки та придатків в ізольованому вигляді або в різних поєднаннях. Також виявлено, що у 97 пацієнток $(21,56 \pm 1,94) \%$ зустрічалися онкозахворювання, що може вказувати на генетичну схильність даного захворювання.

Звертає на себе увагу досить висока частота ендокринних порушень, які мали місце у найближчих родичів хворих на ПШМ: у $113(25,11 \pm 2,04) \%$ обстежених у батьків відмічено проблеми з молочними залозами, в $62(13,78 \pm 1,62) \%$ - цукровий діабет, а в $59(13,11 \pm 1,59)$ \% виявлено захворювання щитоподібної залози, що в сумі склало $(52,00 \pm 2,36) \%$ (OR=9,81; $95 \%$ Cl: $(0,68-10,53) ; p<0,002)$.

Таким чином, серед чинників, що мають прогностичне значення в розвитку ПшМ, можна назвати чинник обтяженої спадковості, частіше по материнській лінії (родичі першого ступеня), в основному доброякісними і злоякісними пухлинами статевих органів і пухлинами екстрагенітальної локалізації різної етіології. Крім цього, виявлено високий відсоток захворюваності ендокринного генезу - $(52,00 \pm 2,36) \%$.

Аналітична оцінка вагомості фракторів ризику виникнення ПШМ дозволила припустити, що раннє менархе 
майже втричі збільшує шанси розвитку Пшм (OR=2,72; $95 \%$ Cl: (1,02-5,11); p<0,002), порушення менструального циклу - вдвічі (OR=2,04; 95 \% Cl: $(1,09-3,14) ; p<0,05)$, хронічні запальні захворювання придатків (OR=3,14; $95 \%$ Cl: $(0,91-5,14) ; p<0,05)$.

Аналіз перенесених дитячих інсрекцій (кір, краснуха, вітряна віспа, скарлатина, епідемічний паротит у різних поєднаннях), захворювань ЛОР-органів (хронічний тонзиліт, викривлення носової перегородки, гайморит тощо), а також грипу і ГРВІ у пацієнток дозволив виявити досить високу частоту $((91,33 \pm 1,33) \%)$ інфекційних захворювань, перенесених у дитячому і юнацькому віці.

Ми проаналізували перенесені хронічні екстрагенітальні захворювання в обстежуваній групі. У більшої половини хворих було відмічено поєднання двох або більше перенесених екстрагенітальних захворювань.

Захворювання ШКТ і органів гепатобіліарного комплексу (хронічні гастрити, ентероколіти, холецистити, гепатити) виявлено у 5,7 раза частіше (OR=5,27; $95 \%$ Cl: $(1,89-12,03) ;$ p<0,05) у досліджуваній групі пацієнтів; захворювання серцево-судинної системи (гіпертонічна хвороба, гіпотонія) - в 53 (48,2 \%), диссрункція щ3 - у 18 (16,4 \%), мастопатія, хронічні запальні захворювання верхніх дихальних шляхів - у 34 (30,9\%), хронічний пієлонесрит - в 18 (16,4 \%) хворих.

Всі обстежені жінки пред'являли скарги на мено- і метрорагії. Виникнення циклічного больового синдрому, що посилюється, з моменту менархе виявили в $(86,00 \pm 1,64) \%$ пацієнток. Тривалість менструацій складала від 7 до 10-12 днів, при цьому тривалість МЦ варіювала від 21 до 26 днів, і чим інтенсивніший був больовий синдром за шкалою 3. Mac Laverty, P. Shav, тим коротший був менструальний цикл. Дисметаболічні прояви (ФКМ, диссрункція щитоподібної залози $)$ - (OR=5,11; 95 \% Cl: $(1,61-9,503) ; p<0,002)$.

У $(17,56 \pm 1,79) \%$ хворих із ПшМ в анамнезі були одні пологи, у $(8,22 \pm 1,29)$ \% - 1-2 мимовільних викидні і вагітності різних термінів гестації, що завмерли, в $(3,11 \pm 0,82) \%$ - післяпологові ускладнення (лохіометра, субінволюція матки, метроендометрит). Безпліддя так званого нез'ясованого генезу, тобто при прохідних трубах (підтверджених гістеросальпінгографрією), овуляторних циклах, фертильній спермі й позитивному тесті пенетрації, виявлено у $(51,33 \pm 2,36) \%$ жінок. Безпліддя було первинним у $(81,00 \pm 1,61) \%$ пацієнток, вторинним - у $(19,00 \pm 1,16) \%$. Тривалість безпліддя склала $(5,7 \pm 2,2)$ року.

Обговорення результатів дослідження.

Проведені дослідження свідчать про необхідність віднесення жінок із вказаними чинниками до групи високого ризику щодо розвитку ускладненого перебігу ПшМ. Раннє менархе майже втричі збільшує шанси розвитку ПШМ (OR=2,72; 95 \% Cl: $(1,02-5,11)$; $p<0,002)$, порушення менструального циклу - вдвічі (OR=2,04; $95 \%$ Cl: $(1,09-3,14) ;$ p<0,05), стрес, вища освіта, жителі міста (OR=2,27; 95 \% Cl: $(1,11-3,63) ; p<0,05)$, захворювання ШКТ й органів гепатобіліарного комплексу $(\mathrm{OR}=5,27$; $95 \%$ Cl: (1,89-12,03); p<0,05), часто рецидивуючі запальні захворювання придатків (OR=3,14; 95 \% Cl: $(0,91-5,14)$; $\mathrm{p}<0,05)$, дисметаболічні прояви (диссункція щитоподібної залози $)$ - (OR=5,11; 95 \% Cl: $(1,61-9,503) ; p<0,002)$. Проведено клініко-статистичний аналіз перебігу ендометріозу після розробленого комплексного лікування порівняно із загальноприйнятою терапією.

Таким чином, результати досліджень та їх оцінка дали можливість обґрунтувати і сорормулювати висновки та практичні рекомендації щодо лікування пацієнтів із захворюваннями шийки матки.

ВИСНОВКИ. 1. У пацієнток із патологією шийки матки доцільно проводити комплексну оцінку вагінальної мікстінфекції та відповідну санацію і відновлення нормальної мікрофрлори для профрілактики розвитку патології шийки матки.

2. Пацієнток із патологією шийки матки необхідно обстежувати на наявність вірусної інфекції і при тривалій персистенції ВПЛ та вірусів родини герпесу понад один рік необхідно застосовувати методику противірусної санації у широкій клінічній практиці.

ПЕРСПЕКТИВИ ПОДАЛЬШИХ ДОСЛІДЖЕНЬ. ПОшук препаратів з імуноактивною дією в комплексному лікуванні патології шийки матки дозволить підвищити ефрективність елімінації вірусного навантаження цих хворих, покращить кольпоскопічну картину за рахунок зменшення площі ураження шийки матки та дозволить отримати нормалізацію цитологічних обстежень у хворих 3 CIN I.

\section{СПИСОК ЛІТЕРАТУРИ}

1. Хаитов Р. М. Иммунотерапия / под ред. Р. М. Хаитова, Р. И. Атауллаханова, А. Е. Шульженко. - М. : ГЭОТАР-Медиа, 2020. - 768 c. - Режим доступа : https://www.rosmedlib.ru/book/ ISBN9785970453728.html (дата обращения: 27.04.2021).

2. Противовирусная активность пептидных иммуномодуляторов при экспериментальных инфекциях, вызванных вирусами простого герпеса типов 1 и 2 / И. Ф. Баринский, Л. М. Алимбарова, А. А. Лазаренко [и др.] // Вопросы вирусологии. - 2003. - № 5.

3. Дранник Г. Н. Клиническая иммунология и аллергология / Г. Н. Дранник. - 3-е изд., доп. - К. : ООО «Полиграср плюс», 2006. - 482 с.

4. Экстракорпоральная антибиотикотерапия и иммунотерапия в лечении хронических персистирующих урогенитальных инфекций у гинекологических больных / А. Н. Дробинская, Н. А. Хонина, Н. М. Пасман [и др.] // Акушерство и гинекология. - 2006. - № 5.
5. Зайков С. В. Лиастен: новый оригинальный иммуномодулятор / С. В. Зайков // Аптека. - 2006. - № 41 (562).

6. Комплексное лечение пациенток с локальным и распространенным кондиломатозом шейки матки / И. Б. Манухин, Г.Н.Минкина, М. М. Высоцкий, О. Г. Харлова // Вопросы гинекологии, акушерства и перинатологии. -2005. - T. 4, № 6. - C. 20-24.

7. Cervical intraepithelial neoplasia grade 3 in a patient following Gardasil vaccination / B. McLucas, E. Vail, K. J. Chua, G. Walt // BMJ Case Rep. - 2019. - Vol. 12 (8). - pii: e230366. DOI: $10.1136 / \mathrm{bcr}-2019-230366$.

8. Назарова Н. М. ВПЧ и ассоциированные с ним заболевания шейки матки у женщин, применяющих гормональные методы контрацепции: лечебно-диагностическая тактика при аномальных результатах цитологии / Н. М. Назарова, К. И. Гусаков, Е. Г. Сычева // Медицинский совет. -2019. - № 7. - С. 34-38. DOI: https://doi.org/10.21518/2079-701X-2019-7-34-38. 
9. Cervical cancer screening programs in europe: the transition towards HPV Vaccination and Population-Based HPV Testing / A. C. Chrysostomou, D. C. Stylianou, A. Constantinidou, L. G. Kostrikis // Viruses. - 2018. - Vol. 10 (12). - P. 729. DOI: 10.3390/v10120729.

10. Предопухолевая патология шейки матки: объем компетенции врача-гинеколога / В. Н. Запорожан, Т. Ф. Татарчук, В. Г. Дубинина [и др.] // Репродуктивная эндокринология. 2013. - № 4 (12). - C. 7-17.

11. Хаитов Р. М. Иммуномодуляторы: механизм действия и клиническое применение / Р. М. Хаитов, Б. В. Пинегин // Иммунология. - 2003. - № 4. - С. 196-203.

12. Иммунотерапия иноекционных послеоперационных осложнений с помощью нового иммуностимулятора ликопида / Р. М. Хаитов, Б. В. Пинегин, А. А. Бутаков [и др.] // Иммунология. - 1994. - № 2. - С. 47-50.

13. Опыт применения препарата бластен (лиастен) у больных с разными формами злокачественных новообразований / С. И. Шпилевая, О.В.Пономарьова, В.М.Пивнюк, Л. Н. Шинкаренко // Сучасні проблеми експериментальної клінічної онкології : тези VII міжнародної конференції молодих онкологів. - К., 2006. - С. 87.

\section{REFERENCES}

1. Khaitova, R.M., Ataullakhanova, R.I., \& Shulzhenko, A. Ye. (Eds.). (2020). Immunoterapiia [Immunotherapy]. Moscow: GEOTAR-Media. Retrieved from: https://www.rosmedlib.ru/book/ ISBN9785970453728.html [in Russian].

2. Barinskiy, I.F., Alimbarova, L.M., \& Lazarenko, A.A. (2003). Protivovirusnaya aktivnost peptidnykh immunomodulyatorov pri eksperimentalnykh infektsiyakh, vyzvannykh virusami prostogo gerpesa tipov 1 i 2 [Antiviral activity of peptide immunomodulators in experimental infections caused by herpes simplex viruses types 1 and 2]. Voprosy virusologii - Virology Issues, 5 [in Russian].

3. Drannik, G.N. (2006). Klinicheskaya immunologiya $i$ allergologiya [Clinical immunology and allergology]. Kyiv: OOO «Poligraf plyus» [in Russian].

4. Drobinskaya, A.N., Khonina, N.A., \& Pasman, N.M. (2006). Ekstrakorporalnaya antibiotikoterapiya i immunoterapiya v lechenii khronicheskikh persistiruyushchikh urogenitalnykh infektsiy u ginekologicheskikh bolnykh [Extracorporeal antibiotic therapy and immunotherapy in the treatment of chronic persistent urogenital infections in gynecological patients]. Akusherstvo i ginekologiya - Obstetrics and Gynecology, 5 [in Russian].

5. Zaykov, S.V. (2006). Liasten: novyi originalnyi immunomodulyator [Liasten: a new original immunomodulator] Apteka - Pharmacy, 41 (562) [in Russian].

6. Manukhin, I.B., Minkina, G.N., Vysotskiy, M.M., \& Kharlova, O.G. (2005). Kompleksnoye lecheniye patsiyentok s lokalnym i rasprostranennym kondilomatozom sheyki matki [Complex treatment of patients with local and widespread condylomatosis of the cervix]. Voprosy ginekologii, akusherstva i perinatologii - Issue of Gynecology, Obstetrics and Perinatology, 4, 6, 20-24 [in Russian].

7. McLucas, B., Vail, E., Chua, K.J., \& Walt, G. (2019). Cervical intraepithelial neoplasia grade 3 in a patient following Gardasil vaccination. BMJ Case Rep., 12 (8), pii: e230366. DOI: 10.1136/bcr-2019-230366.

8. Nazarova, N.M., Gusakov, K.I., \& Sycheva, E.G. (2019). VPCH i assotsiirovannyye s nim zabolevaniya sheyki matki u zhenshchin, primenyayushchikh gormonalnyye
14. Azuma I. Review: Inducer of cytokines in vivo: overview of field and romurtide experience / I. Azuma // Int. J. Immunolpharmac. - 1992. - Vol. 14. - P. 487-496.

15. Werner G. H. Immunostimulating agents: what next? A review of their present and potential medical applications / G. H. Werner, P. Jolles // Eur. J. Immunol. - 1996. - Vol. 242. - P. 1-19.

16. CTV Report Consortium. ICTV Virus Taxonomy Profile: Papillomaviridae / K. Van Doorslaer, Z. Chen, H. U. Bernard [et al.] // J. Gen. Virol. - 2018. - Vol. 99 (8). - P. 989-990. DOI: $10.1099 /$ jgv.0.001105.

17. Cryoelectron microscopy maps of human papillomavirus 16 reveal L2 densities and heparin binding site / J. Guan, S. M. Bywaters, S. A. Brendle, [et al.] // Structure. - 2017. Vol. 25:253-263. DOI: 10.1016/j.str. 2016.12.001.

18. Cervical intraepithelial neoplasia grade 3 in a patient following Gardasil vaccination / B. McLucas, E. Vail, K. J. Chua, G. Walt // BMJ Case Rep. - 2019. - Vol. 12 (8). - pii: e230366. DOI: $10.1136 /$ bcr-2019-230366.

19. Peculiarities of uterine cavity biocenosis in patients with different types of endometrial hyperproliferative pathology / N. Y. Horban, I. B. Vovk, T. O. Lysiana [et al.] // J. Med. Life. 2019. - Vol. 12 (3). - P. 266-270. DOI: 10.25122/jml-2019-0074.

metody kontratseptsii: lechebno-diagnosticheskaya taktika pri anomalnykh rezultatakh tsitologii [HPV and associated diseases of the cervix uteri in women using hormonal methods of contraception: treatment and diagnostic tactics in case of abnormal results of cytology]. Meditsinskiy sovet - Medical Advice, 7, 34-38. DOI: https://doi.org/10.21518/2079701X-2019-7-34-38 [in Russian].

9. Chrysostomou, A.C., Stylianou, D.C., Constantinidou, A., \& Kostrikis, L.G. (2018). Cervical cancer screening programs in europe: the transition towards HPV Vaccination and PopulationBased HPV Testing. Viruses, 10 (12), 729. DOI: 10.3390/ v10120729.

10. Zaporozhan, V.N., Tatarchuk, T.F., Dubinina, V.G., Volodko, N.A., \& Silina, N.K. (2013). Predopukholevaya patologiya sheyki matki: obyem kompetentsii vracha-ginekologa [Pretumor pathology of the cervix: the scope of competence of a gynecologist]. Reproduktivnaya endokrinologiya - Reproductive Endocrinology, 4 (12), 7-17 [in Russian].

11. Khaitov, R.M., \& Pinegin, B.V. (2003). Immunomodulyatory: mekhanizm deystviya i klinicheskoye primeneniye [Immunomodulators: mechanism of action and clinical application]. Immunologiya - Immunology, 4, 196-203 [in Russian].

12. Khaitov, R.M., Pinegin, B.V., \& Butakov, A.A. (1994). Immunoterapiya infektsionnykh posleoperatsionnykh oslozhneniy s pomoshchyu novogo immunostimulyatora likopida [Immunotherapy of infectious postoperative complications using a new immunostimulant lycopid]. Immunologiya - Immunology, 2, 47-50 [in Russian]

13. Shpilevaya, S.I., Ponomarova, O.V., Pivnyuk, V.M., \& Shinkarenko, L.N. (2006). Opyt primeneniya preparata blasten (liasten) u bolnykh s raznymi formami zlokachestvennykh novoobrazovaniy [Experience of using the drug blasten (liasten) in patients with different forms of malignant neoplasms]. Abstracts of the YII International Conference of Young Oncologists: Suchasni problemy eksperymentalnoi i klinichnoi onkolohii - Modern Problems of Experimental and Clinical Oncology. Kyiv [in Russian].

14. Azuma, I. (1992). Review: Inducer of cytokines 
in vivo: overview of field and romurtide experience. Int. J. Immunolpharmac, 14, 487-496. DOI: 10.1016/01920561(92)90180-s.

15. Werner, G.H., \& Jolles, P. (1996). Immunostimulating agents: what next? A review of their present and potential medical applications. Eur. J. Immunol., 242, 1-19. DOI: 10.1111/j.1432-1033.1996.0001r.x.

16. Van Doorslaer, K., Chen, Z., Bernard, H.U., Chan, P.K.S., DeSalle, R., Dillner, J., \& Burk, R.D. (2018). ICTV Report Consortium. ICTV Virus Taxonomy Profile: Papillomaviridae. J. Gen. Virol., 99 (8), 989-990. DOI: 10.1099/jgv.0.001105.

17. Guan, J., Bywaters, S.M., Brendle, S.A., Ashley, R.E., Makhov, A.M., ..., \& Hafenstein, S. (2017). Cryoelectron microscopy maps of human papillomavirus 16 reveal L2 densities and heparin binding site. Structure, 25 (2), 253-263. DOI: 10.1016/j.str. 2016.12.001.

18. McLucas, B., Vail, E., Chua, K.J., \& Walt, G. (2019). Cervical intraepithelial neoplasia grade 3 in a patient following Gardasil vaccination. BMJ Case Rep., 12 (8), pii: e230366. DOI: 10.1136/bcr-2019-230366.

19. Horban, N.Y., Vovk, I.B., Lysiana, T.O., Ponomariova, I.H., \& Zhulkevych, I.V. (2019). Peculiarities of uterine cavity biocenosis in patients with different types of endometrial hyperproliferative pathology. J. Med. Life, 12 (3), 266-270. DOI: 10.25122/jml-2019-0074.

Отримано 12.04.21

Прийнято до друку 10.05.21

Електронна адреса для листування: appag@ukr.net 